\title{
Povezanost religioznosti te stavova i iskustava o vjerskoj slobodi kod religiozno deklariranih mladih u Hrvatskoj
}

Marijana Kompes*
marijana.kompes@unicath.hr

\author{
https://doi.org/10.31192/np.16.2.1 \\ UDK: 342.731:272-053.6(497.5) \\ 27-184.3:342.731 \\ Izvorni znanstveni rad / Original scientific paper \\ Primljeno: 15. ožujka 2018. \\ Prihvaćeno: 14. lipnja 2018.
}

Vjerska sloboda je jedno od najstarijih, temeljnih i neotudivih ljudskih prava. Istovremeno, kao ljudsko pravo, vjerska sloboda je višedimenzionalno pravo koje štiti individualnu i kolektivnu dimenziju slobode (forum internum i forum externum). Polazeći iz perspektive socijalnog nauka Katoličke crkve teorijski dio rada prikazuje vjersku slobodu kao višedimenzionalno ljudsko prava i daje uvid u odnos Katoličke crkve i vjerske slobode kroz povijest. Empirijski dio rada temelji se na hrvatskom istraživanju »Religija i ljudska prava« (2014.) koje je provedeno u sklopu međunarodnog empirijskog istraživačkog programa »Religion and Human Rights" (2012.-2019.). Na temelju navedenog istraživanja ovaj rad istražuje povezanost religioznosti te stavova $i$ iskustava o vjerskoj slobodi (forum internum i forum externum) kod religiozno deklariranih mladih u Hrvatskoj u dobi od 17 do 19 godina, od kojih većinu čine katolici. Rezultati empirijske analize (višestruke regresije) pokazuju da prediktor religioznosti utječe na stavove $i$ iskustva religiozno deklariranih mladih u Hrvatskoj s obzirom na vjersku slobodu u obje njezine dimenzije.

Ključne riječi: vjerska sloboda, religioznost, religiozno deklarirani mladi u Hrvatskoj, Katolička crkva.

\footnotetext{
* Dr. sc. Marijana Kompes, mag. phil., poslijedoktorandica na Katedri za teologiju Hrvatskoga katoličkog sveučilišta u Zagrebu, Ilica 242, HR-10000 Zagreb.
} 


\section{Uvod}

Vjerska sloboda kao neotuđivo pravo koje pripada svim ljudima čini »temeljni kamen strukture ljudskih prava i zbog toga je nenadomjestiv faktor kada je riječ o dobru pojedinca i društva kao cjeline, a jednako tako i osobnog ispunjenja svakog pojedinca«. ${ }^{1}$ Kao građansko pravo, vjerska sloboda osigurava zaštitu individualne i kolektivne dimenzije slobode, što ukazuje na činjenicu da je vjerska sloboda u sebi višedimenzionalno ljudsko pravo.

Polazeći iz perspektive kršćanske socijalne etike i socijalnoga nauka Katoličke crkve, ovaj rad ima za cilj pružiti uvid u povezanost religioznosti te stavova i iskustava o vjerskoj slobodi kod religiozno deklariranih mladih u Hrvatskoj u dobi od 17 do 19 godina. Empirijski dio rada temelji se na rezultatima hrvatskog istraživanja »Religija i ljudska prava« (2014.) koje je provedeno u sklopu međunarodnog empirijskog istraživačkog programa »Religion and Human Rights« (2012.-2019.). ${ }^{2}$ Prema posljednjem popisu stanovništva iz 2011. godine $86,3 \%$ građana Hrvatske se izjasnilo kao katolici, 4,44 \% kao pravoslavni, 1,5 \% kao muslimani, 4,6 \% nisu vjernici, dakle ateisti i agnostici, 2,2 \% građana se nije izjasnilo, $1,1 \%$ ostali i nepoznato. ${ }^{3}$ Podatci za opću populaciju svrstavaju Hrvatsku među najreligioznija društva u Europi, a u radu će biti prikazani rezultati istraživanja »Religija i ljudska prava« (2014.) koji se odnose na mlade tri godine kasnije. Kada je riječ o katolicima, ljudska prava i vjerska sloboda čine od Drugoga vatikanskog sabora i proglašenja deklaracije »Dignitatis humanae« (1965.), jednu od glavnih tema kršćanske socijalne etike i socijalnog nauka Katoličke crkve, kako će biti prikazano u posebnom poglavlju. Rad je podijeljen na ukupno šest poglavlja. Nakon uvoda u prvom poglavlju se prikazuje vjerska sloboda kao višedimenzionalno ljudsko pravo i odnos s Katoličkom crkvom. U drugom dijelu rada prikazan je konceptualni model i metoda istraživanja koje je provedeno u ovome radu. Rezultati istraživanja povezanosti religioznosti te stavova i iskustava o vjerskoj slobodi (forum internum i forum externum) kod

\footnotetext{
${ }^{1}$ IVAN PAVAO II., Religious freedom. Condition of peace, Poruka pape Ivana Pavla II. prigodom proslave Svjetskog dana mira, 1. siječnja 1988., Uvodni dio, http://w2.vatican.va/content/johnpaul-ii/en/messages/peace/documents/hf_jp-ii_mes_19871208_xxi-world-day-for-peace. html (27.06.2017). Jedanaest godina kasnije papa Ivan Pavao II. je, govoreći o vjerskoj slobodi prigodom Svjetskoga dana mira 1998., istaknuo da vjerska sloboda konstituira samo srce ljudskih prava (usp. IVAN PAVAO II., Respect for human rights: the secret of true peace. Poruka pape Ivana Pavla II. prigodom proslave Svjetskog dana mira, 1. siječnja 1999, br. 5), http:// w2.vatican.va/content/john-paul-ii/en/messages/peace/documents/hf_jp-ii_mes_14121998_ xxxii-world-day-for-peace.html (27.06.2017).

${ }^{2}$ Hrvatsko istraživanje »Religija i ljudska prava« (2014.) i međunarodni projekt »Religion and Human Rights« (2012.-2019.) predstavljeni su u poglavlju 2. Konceptualni model i metoda istraživanja ovog rada.

${ }^{3}$ Državni zavod za statistiku Republike Hrvatske, Popis stanovništva, kućanstava i stanova 2011. Stanovništvo prema državljanstvu, narodnosti, vjeri i materinskom jeziku, 2013, 14, http:// www.dzs.hr/Hrv_Eng/publication/2012/SI-1469.pdf (24.04.2017).
} 
religiozno deklariranih mladih u Hrvatskoj sistematizirani su trećem poglavlju u dva tematska podnaslova. Na kraju rada slijedi zaključak.

\section{Vjerska sloboda - višedimenzionalno ljudsko pravo i odnos s Katoličkom crkvom}

\subsection{Vjerska sloboda - višedimenzionalno ljudsko pravo}

Kao ljudsko pravo koje štiti pojedinca i područje njegove slobode, vjerska sloboda treba biti ustavno priznata i tako postati građansko pravo, kako ističe Deklaracija »Dignitatis humanae« u br. 4 i $15 .{ }^{4} \mathrm{U}$ »Općoj deklaraciji o ljudskim pravima« (1948.) ističe se u čl. 18:

"Svatko ima pravo na slobodu mišljenja, savjesti i vjeroispovijedi; to pravo uključuje slobodu promjene vjeroispovijedi ili uvjerenja i slobodu da pojedinačno ili u zajednici s drugima, javno ili privatno, iskazuje svoju vjeroispovijed ili uvjerenje poučavanjem, bogoslužjem, praktičnim vršenjem i obredima. ${ }^{5}$

Pojam »uvjerenje« je uključen kao zaštita prava na izražavanje ne-religioznih ili ateističkih uvjerenja. ${ }^{6}$ Područje zaštite koje pokriva vjerska sloboda ukazuje da je ona višedimenzionalno ljudsko pravo, dakle da uključuje individualnu i kolektivnu dimenziju slobode. Stoga se prava koja štiti vjerska sloboda klasificiraju u dva područja: forum internum i forum externum. Forum internum štiti privatni, unutarnji život $\mathrm{u}$ kojem sloboda misli, savjesti i religije apsolutno vlada. U vremenima rata i javne opasnosti nije dopušteno otuđenje te slobode, ${ }^{7}$ osobito ne od strane države. ${ }^{8}$ Drugo zaštitno područje vjerske slobode obuhvaća javnu manifestaciju religije ili uvjerenja (forum externum), osobno ${ }^{9}$

${ }^{4}$ DRUGI VATIKANSKI KONCIL, Dignitatis humanae. Deklaracija o vjerskoj slobodi (7.XII.1965), u: Dokumenti, Zagreb, Kršćanska sadanjost, 2008.

${ }^{5}$ UJEDINJENI NARODI, Opća deklaracija o ljudskim pravima, https://narodne-novine.nn.hr/ clanci/medunarodni/2009_11_12_143.html (17.11.2016) [dalje: Opća deklaracija...].

${ }^{6}$ Natan LERNER, The Nature and Minimum Standards of Freedom of Religion or Belief, $\mathrm{u}$ : Tore LINDHOLM i dr. (ur.), Facilitating Freedom of Religion or Belief. A Deskbook, The Hague/Boston, Martinus Nijhoff Publishers, 2004, 63-83, 67-68.

7 Ujedinjeni narodi, Međunarodni pakt o građanskim i političkim pravima, čl. 18, https://pravosudje.gov.hr/UserDocsImages/dokumenti/Pravo\%20na\%20pristup\%20informacijama/ Zakoni\%20i\%20ostali\%20propisi/UN\%20konvencije/Medjunarodni_pakt_o_gradjanskim_i_ politickim_pravima_HR.pdf (05.07.2017) [dalje: Medunarodni pakt o gradanskim...]; Opća deklaracija..., čl. 18; Vijeće Europe, Europska Konvencija za zaštitu ljudskih prava i temeljnih sloboda, čl. 9, https://www.zakon.hr/z/364/(Europska)-Konvencija-za-za\%C5\%A1titu-ljudskih-prava-i-temeljnih-sloboda (05.07.2017) [dalje: Europska Konvencija za zaštitu ljudskih prava...].

8 Usp. Medunarodni pakt o građanskim..., čl. 18 (2).

${ }^{9}$ M. Todd PARKER, The Freedom to Manifest Religious Belief: An Analysis of the Necessity Clauses of the ICCPR and the ECHR, Duke Journal of Comparative E International Law, 17 
ili u zajednici u obliku bogoslužja, praktičnog vršenja, obreda i poučavanja. ${ }^{10}$ John Courtney Murry sistematizira slobodno očitovanje religije $u$ tri sastavna elementa: crkvena ili zajednička sloboda, sloboda religijskog udruživanja i sloboda religijskog izražavanja. ${ }^{11}$

Pravo na vjersku slobodu s obzirom na forum externum ima pozitivnu i negativnu stranu. Pozitivna vjerska sloboda je pravo manifestiranja vlastite relgije kroz bogoslužje, praktično vršenje, obreda i poučavanja privatno i u javnosti. Negativna vjerska sloboda se odnosi na pravo da se ne bude ometan religijskom praksom drugih. Obje strane imaju jednaku važnost. ${ }^{12} \mathrm{U}$ povijesti ljudskih prava upravo je u razdoblju Drugoga svjetskog rata postalo evidentno kako upravo država može teško kršiti prava svojih vlastitih građana ako proizvoljno interpretira ljudska prava. ${ }^{13} \mathrm{Da}$ bi se spriječilo ponavljanje toga, ljudska prava su postala predmet i međunarodne brige, a sam proces ostvarivanja toga je poznat kao internacionalizacija ljudskih prava, a time i vjerske slobode. ${ }^{14}$ Tako su od sredine 1940-ih godina do naših dana proglašeni mnogi međunarodni dokumenti i regionalne norme ${ }^{15} \mathrm{koji}$, iako usmjereni prema zaštiti i drugih specifičnih ljudskih prava, adresiraju i vjersku slobodu. ${ }^{16} \mathrm{U}$

(2006) 91, 91-129, 93; Adrian LORETAN i dr., Freiheit und Religion. Die Anerkennung weiterer Religionsgemeinschaften in der Schweiz, Münster, Liт, 2014, 54.

${ }^{10}$ Usp. Međunarodni pakt o gradanskim..., čl. 18; Opća deklaracija..., čl. 18; Europska Konvencija za zaštitu ljudskih prava..., čl. 9.

${ }^{11}$ Usp. John Courtney MURRAY, The Problem of Religious Freedom, Theological Studies, 25 (1964) 503-575, 517-518.

${ }^{12}$ Ingeborg GABRIEL, Freedom of Religion, u: Manfred NOWAK i dr. (ur.), All Human Rights for All. Vienna Manual on Human Rights, Graz - Beč, Neuer Wissenschaftlicher Verlag, 392395, 393; Manfred NOWAK, Permissible Restrictions on Freedom of Religion or Belief, u: Tore LINDHOLM i dr. (ur.), Facilitating Freedom of Religion or Belief. A Deskbook, The Hague Boston, Martinus Nijhoff Publishers, 2004, 147-172, 170.

${ }^{13}$ Hans-Georg ZIEBERTZ i dr., Menschenrechte. Trotz oder wegen Religion? Eine empirische Studie unter jungen Menschen, Muslimen und Nicht-Religiösen, Münster, LIT, 2012, 13.

${ }^{14}$ Jedno od prvih prava, temeljnih sloboda, artikuliranih od Franklina D. Roosvelta i naglašenih u Deklaraciji Ujedinjenih naroda 1942. godine je bilo upravo pravo na slobodno očitovanje religije (Lerner, The Nature and Minimum..., 67-68). Time što je vjerska sloboda adresirana u Općoj deklaraciji..., čl. 18 označena je snažnija »internacionalizacija« vjerske slobode.

${ }^{15}$ Primjerice Europska konvencija za zaštitu ljudskih prava...; Američka konvencija o ljudskim pravima; Afrička povelja o ljudskim pravima i pravima naroda; Povelja o temeljnim pravima Europske unije; Lisabonski ugovor.

${ }^{16} \mathrm{Na}$ međunarodnoj razini je osobito važna, s obzirom na vjersku slobodu, studija Arcota Krishnaswamija koja je predana 1960. godine. Ona je važan korak UN-a u identifikaciji i zaštiti vjerske slobode te je imala važan utjecaj na Deklaraciju iz 1981. godine (usp. Study of Discrimination in the Matter of Religious Rights and Practices: Report of Mr. Arcot KRISHNASWAMI, Special Rapporteur of the Sub-Commission on Prevention of Discrimination and Protection of Minorities, 12 U.N. ESCOR Sub-Comm'n on Prevention of Discrimination and Protection of Minorities (Agenda Item 5), U.N. Doc. E/CN.4/Sub.2/200/Rev.1, 1960). Osim već spomenutog Međunarodnog pakta o građanskim i političkim pravima (1966.) (čl. 18-20, 27), od odlučujućeg značenja za vjersku slobodu je bila »Konferencija za europsku sigurnost i suradnju« (KESS) (1973-1975) gdje su ljudska prava tematizirana u sklopu »treće košare« (usp. John J. MARESCA, To Helsinki. The Conference on Security and Co-operation 
komunističkom dijelu Europe one nisu bile primijenjene. Nakon Drugoga svjetskog rata dogodili su se važni koraci u Katoličkoj crkvi kada je riječ o njezinom pozicioniranju prema vjerskoj slobodi i ljudskim pravima, što će biti prikazano u sljedećem poglavlju.

\subsection{Vjerska sloboda i Katolička crkva}

S obzirom na vjersku slobodu kršćanstvo ima dug povijeni razvoj od religio illicita na samim počecima u okviru Rimskog Carstva i statusa progonjenje vjerske manjine u prvim kršćanskim stoljećima do Solunskog edikta cara Teodozija I. 380. godine, kada je kršćanstvo postalo službenom religijom Rimskoga Carstva. Nakon reformacije i konflikata za vjersku istinu u konfesionalnim ratovima 16. i 17. stoljeća, razvijena je teorija vjerske tolerancije prema kojoj nema pravo osoba, nego »istina« ima pravo. Kao što Ernst-Wolfgang Böckenförde ukazuje, tu nije bilo riječ o pravnoj teoriji nego o teoriji moći. ${ }^{17} \mathrm{U} 18$. stoljeću »Deklaracija o pravim čovjeka i građanina« (1789.) jest temeljna deklaracija ljudskih sloboda, uključujući i vjersku slobodu (čl. 10) na europskom tlu, ali izvor Deklaracije su bili glavni mislioci francuskog prosvjetiteljstva čiji je stav prema religiji bio označen kao »studious ferocity ${ }^{18}{ }^{18}$ kako Alexis de Tocqueville formulira. Voltaire tu činjenicu izražava sintagmom »Ecrasez l'infâme «. ${ }^{19}$ Planirana podjela između politike i religije je dovela do neprijateljstva prema religiji i crkvi, ${ }^{20}$ i to u ime vjerske slobode, dok je u Sjevernoj Americi vladao potpuno drugačiji stav prema religiji i vjerskoj slobodi. ${ }^{21}$

U svjetlu izrazito negativnog iskustva vjerske slobode u kontekstu Francuske revolucije, Sveta Stolica je favorizirala konfesionalnu državu koja je štitila pravu vjeru te je odbijala moderno shvaćene vjerske slobode, a time i ljudska prava u

in Europe 1973-1975, Durham, Duke University Press, 1987, 144-145) kao i u sklopu VII. principa »Dekaloga«. Godine 1981. proglašena je od UN-a »Deklaraciju o ukidanju svih oblika nesnošljivosti i diskriminacije na temelju religije i uvjerenja«. Dvije prateće KESS konferencije održane su u Madridu (1981-1983), kao i zaključni dokument konferencije u Beču 1989., koje su pružile daljnji doprinos promociji vjerske slobode. U godini 1992. UN je proglasio »Deklaraciju o pravima osoba koje pripadaju nacionalnim ili etničkim, vjerskim i jezičnim manjinama«.

${ }^{17}$ Ernst-Wolfgang BÖCKENFÖRDE, Religionsfreiheit. Die Kirche in der modernen Welt, Freiburg - Basel - Beč, Herder, 1990, 23-24.

${ }^{18}$ Alexis de TOCQUEVILLE, The Old Regime and the French Revolution, New York, Garden City, $1955,6$.

${ }^{19}$ Pod »l'infâme« Voltaire misli na Katoličku crkvu (usp. René POMEAU, La religion de Voltaire, Paris, Librairie A. G. Nizet, 2000, 476; Germana CAROBENE, Tolleranza e libertà religiosa nel pensiero di Voltaire, Torino, Giappichelli, 2000, 93).

${ }^{20}$ Paul WUTHE, Für Menschenrechte und Religionsfreiheit in Europa. Die Politik des Heiligen Stuhls in der KSZE/OSZE, Stuttgart, Kohlhammer, 2002, 45.

${ }^{21}$ Izvrstan prikaz različitih koncepcija moderne u Europi i Americi daje: Gertrude HIMMELFARB, The roads to modernity. The British, French and American enlightenments, New York, Vintage, 2005, 50. 
vrijeme Francuske revolucije. Takav stav je bio zadržan sve do pontifikata pape Lava XIII. (1878.-1903.), kada počinje razdoblje »opreznog približavanja« Katoličke crkve vjerskoj slobodi koje će trajati do 1960-ih godina. S Drugim vatikanskim saborom počinje »razdoblje identifikacije« Katoličke crkve s vjerskom slobodom, a time i ljudskim pravima. ${ }^{22} \mathrm{Na}$ početku tog razdoblje, nakon što je papa Ivan XXIII. u enciklici »Pacem in terris« (1963.) stavio osobu u središte te njezina prava i dužnosti, ${ }^{23}$ Katolička crkva je priznala vjersku slobodu i slobodu savjesti kao univerzalno i neotuđivo ljudsko pravo u deklaraciji »Dignitatis humanae« (1965.) na samom kraju Drugoga vatikanskog sabora. John Courtney Murray (1904.-1967.), istaknuti američki isusovac, dao je izvanredan doprinos tom povijesnom obratu. ${ }^{24}$ »Dignitatis humanae« formulira u br. 2: »Ljudska osoba ima pravo na vjersku slobodu « čime je prihvaćena vjerska sloboda. Time je Katolička crkva prihvatila ne samo ljudska prava nego i sekularnu državu ${ }^{25} \mathrm{i}$ pronašla svoje mjesto u okviru civilnog društva.

\section{Konceptualni model i metoda istraživanja}

Vjerska sloboda kao ljudsko pravo je sloboda koja pripada svakom čovjeku. $\mathrm{Na}$ temelju toga, kao i teorijskih postavki ovoga rada, istraživačko pitanje empirijskog dijela glasi: Postoji li, na temelju istraživanja »Religija i ljudska prava« (2014.), povezanost između religioznosti te stavova i iskustava o vjerskoj slobodi (forum internum i forum externum) kod religiozno deklariranih mladih u Hrvatskoj, i - ako da - koja su njezina obilježja? S obzirom na teorijsko soci-

\footnotetext{
${ }^{22}$ Usp. Wuthe, Für Menschenrechte..., 13, 47, 49.

${ }^{23}$ DRUGI VATIKANSKI KONCIL, Pacem in terris. Enciklika o miru svih naroda što ga je utemeljiti na istini, pravednosti, ljubavi i slobodi (11.IV.1963), u: Dokumenti, Zagreb, Kršćanska sadašnjost, br. 9.

${ }^{24}$ Usp. Murray, The Problem of Religious Freedom...; Josef Isensee opisuje figurativno taj događaj kao »kopernikanski obrat « [usp. Josef ISENSEE, Die katholische Kritik an den Menschenrechten. Der liberale Freiheitsentwurf in der Sicht der Päpste des 19. Jahrhundert, u: Ernst-Wolfgang BÖCKENFÖRDE i dr. (ur.), Menschenrechte und Menschenwürde. Historische Voraussetzungen - säkulare Gestalt - christliches Verständnis, Stuttgart, Klett-Cotta, 1987, 141-167; Joseph A. KOMONCHAK, The American Schema. John Courtney Murray and the Elaboration of Dignitatis humanae, u: Karl GABRIEL i dr. (ur.), Religionsfreiheit und Pluralismus. Entwicklungslinien eines katholischen Lernprozesses, Paderborn i dr., Ferdinand Schöningh, 2010, 155-176].

${ }^{25}$ Usp. Ernst-Wolfgang BÖCKENFÖRDE, Staat - Gesellschaft - Kirche, u: Franz BÖCKLE (ur.), Christlicher Glaube in moderner Gesellschaft, Teilband 15, Freiburg - Basel - Beč, Herder, 1982, 6-120; Böckenförde, Religionsfreiheit..., 46.
} 
jalno-etičko polazište ovoga rada, $\mathrm{u}$ istraživanju je fokus stavljen na religiozne ispitanike (pripadnike svih religija) ${ }^{26}$ od kojih većinu čine upravo katolici. ${ }^{27}$

Obrada istraživačkog pitanja temelji se na rezultatima hrvatskog kvantitativnog istraživanja »Religija i ljudska prava« (2014.) koje je provedeno u sklopu međunarodnog empirijskog istraživačkog programa »Religion and Human Rights« (2012.-2019.) koji obuhvaća oko 25 zemalja i 25.000 mladih ljudi radi istraživanja stavova mladih o ljudskim pravima. Koordinator istraživanja je Hans-Georg Ziebertz (Katedra za religioznu pedagogiju, Katoličko-teološkog fakulteta Sveučilišta u Würzburgu, Njemačka), a voditelj istraživanja za Hrvatsku je Gordan Črpić (Odjel za sociologiju, Hrvatsko katoličko sveučilište). ${ }^{28}$

Uzorak hrvatskoga istraživanja »Religija i ljudska prava« (2014.) je reprezentativan i sastoji se od 1286 ispitanika u dobi od 17 do 19 godina ${ }^{29}$ koji pohađaju gimnazije u 20 županija. Uzorak je neprobabilistički. Kvantitativno istraživanje je provedeno od 3. studenog do 5. prosinca 2014. godine na području cijele Hrvatske. Uzorak je kontroliran pomoću sljedećih varijabla: županija i srednja škola (gimnazija). Individualni upitnik je podijeljen svim ispitanicima koji su bili prisutni na nastavi na dan provođenja istraživanja. Unutar županija, učenici gimnazija su proporcionalno zastupljeni sukladno kvoti koje imaju u populaciji učenika gimnazije na nacionalnoj razini.

U empirijskoj obradi istraživačkog pitanja provedena je višestruka regresija. Korišteni su prediktori religioznosti kao bitan faktor indikacije povezanosti religioznosti te stavova i iskustava o vjerskoj slobodi (forum internum i forum externum) kod religiozno deklariranih mladih u Hrvatskoj. Operacionalizacija religioznosti temelji se na istraživanju Gerharda Lenskog »The Religious Factor: A Sociological Study of Religion's Impact on Politics, Economics, and Family Life« (1961. $)^{30} \mathrm{u}$ kojem je razvijen višedimenzionalan pristup proučavanja

\footnotetext{
${ }^{26}$ Prema istraživanju »Religija i ljudska prava« (2014.) 85,5 \% ispitanika se izjasnilo rimokatolicima; 0,8 \% ostalim kršćanima; 0,8 \% muslimanima (sve tradicije); 0,2 \% židovima; 0,2 \% budistima; $0,2 \%$ drugom religioznom pripadnosti; $2,1 \%$ religioznima bez pripadnosti nekoj zajednici. Od 1286 ispitanika 8 ispitanika nije dalo odgovor na pitanje o konfesionalnoj strukturi, tako da je konačan $\mathrm{N}=1278$.

${ }^{27} \mathrm{U}$ konceptualnom smislu studija nastala kao rezultat projekta »Religion and Human Rights 1.0 « i koja se odnosi na Njemačku također razlikuje ispitanike većinskih religija (kršćanstvo, islam) i ne-religiozne (usp. Ziebertz i dr., Menschenrechte..., 2012).

${ }^{28}$ Podatci o istraživanju »Religion and Human Rights « (2012.-2019.) dostupni su na mrežnoj stranici Katedre za religioznu pedagogiju, Katoličko-teološkog fakulteta Sveučilišta u Würzburgu: http://www.rp.theologie.uni-wuerzburg.de/research/religion-and-human-rights-2012-2019/ (11.07.2017).

${ }^{29}$ Tri četvrtine (75,4 \%) ispitanika su imali 18 godina, jedna četvrtina $(23,4 \%)$ je bila godinu dana mlađa, a preostalih 1,2 \% su tek napunili 19 godina. Djevojke su zastupljene sa 63,6\% $(\mathrm{N}=816)$, a mladići s $36,4 \%(\mathrm{~N}=468)$.

${ }^{30}$ Gerhard LENSKI, The Religious Factor. A Sociological Study of Religion's Impact on Politics, Economics, and Family Life, New York, Doubleday, 1961; Gerhard LENSKI, The Religious Factor. A Sociological Study of Religion's Impact on Politics, Economics, and Family Life, New York, Garden City, 1963, 331.
} 
religioznosti sistematiziran u četiri dimenzije religioznosti podijeljene u dvije grupe:

Osobna religioznost:

1. doktrinalna pravovjernost (prihvaćanje propisanog crkvenog nauka);

2. »pobožnost« (važnost privatnog ili osobnog zajedništva s Bogom).

Povezanost s drugim ljudima:

3. religioznost unutar vlastite religijske zajednice (učestalost sudjelovanja u religijskim službama);

4. religioznost izvan vlastite religijske zajednice (društvena interakcija izvan crkvenog okruženja). ${ }^{31}$

Kao kriterijska varijabla korištena je vjerska sloboda koja je operacionalizirana u svojoj multidimenzionalnosti (forum internum i forum externum). Ona je operacionalizirana prema dimenzijama »Opće deklaracije o ljudskim pravima« (1948.) i »Međunarodnog pakta o građanskim i političkim pravima« (1966.). Forum internum obuhvaća slobodu mišljenja, savjesti i vjeroispovijedi. ${ }^{32}$ Forum externum obuhvaća slobodu da se pojedinačno ili u zajednici s drugima, javno ili privatno, iskazuje svoja vjeroispovijed ili uvjerenje poučavanjem, bogoslužjem, praktičnim vršenjem i obredima. ${ }^{33}$ Višestruka regresija će biti provedena u dva modela koji su sistematizirani u sljedećoj tablici s pripadajućom skalom mjerenja:

\footnotetext{
${ }^{31}$ David VOAS, Surveys of Behaviour, Beliefs and Affiliation. Micro-Quantitative, u: James A. BECKFORD i dr. (ur.), The SAGE Handbook of the Sociology of Religion, Los Angeles i dr., Sage Publications, 2007, 144-166, 146; Charles GLOCK, The Religious Factor by Gerhard Lenski, Political Science Quarterly, 77 (1963) 1, 152-154, 331.

${ }^{32}$ Usp. čl. 18 Medunarodnog pakta o gradanskim..., čl. 18 Opće deklaracije... i čl. 9 Europske konvencije o zaštiti ljudskih prava...; u odnosu na državu osobito čl. 18 (2) Međunarodnog pakta o gradanskim...

${ }^{33}$ Usp. čl. 18 Međunarodnog pakta o gradanskim..., čl. 18 Opće deklaracije... i čl. 9 Europske konvencije o zaštiti ljudskih prava...
} 
Tablica 1. Konceptualni model višestruke regresije.

\begin{tabular}{|c|c|c|c|c|}
\hline $\begin{array}{c}\text { Broj } \\
\text { modela } \\
\text { višestruke } \\
\text { regresije }\end{array}$ & $\begin{array}{l}\text { Kriterijska varijabla } \\
\qquad-y\end{array}$ & $\begin{array}{l}\text { Skala } \\
\text { mjerenja } \\
\text { - kriterij }\end{array}$ & Prediktori - $\mathbf{x}$ & $\begin{array}{c}\text { Skala } \\
\text { mjerenja } \\
\text { - prediktori }\end{array}$ \\
\hline \multirow{6}{*}{$\begin{array}{l}1 \\
\mathrm{M} \\
\mathrm{O} \\
\mathrm{D} \\
\mathrm{E} \\
\mathrm{L}\end{array}$} & \multirow{6}{*}{\begin{tabular}{|l} 
Vjerska sloboda - \\
forum internum \\
(Koliko ste često \\
osobno bili \\
nepravedno tretirani \\
zbog religijske \\
pripadnosti?)
\end{tabular}} & \multirow{6}{*}{$\begin{array}{l}1 \text { (nikada) } \\
\text { do } 5 \text { (vrlo } \\
\text { često) }\end{array}$} & \begin{tabular}{|c|} 
RELIGIOZNOST \\
Dimenzija: Osobna religioznost \\
\end{tabular} & \\
\hline & & & $\begin{array}{c}\mathrm{X}_{1}-\text { doktrinarna } \\
\text { pravovjernost } \\
\text { (Vjerujem da je Bog temelj } \\
\text { svega što postoji.) } \\
\end{array}$ & $\begin{array}{c}\text { od } 1 \text { (ne } \\
\text { slažem se) do } \\
5 \text { (slažem se) }\end{array}$ \\
\hline & & & $\begin{array}{c}\mathrm{X}_{2}-\text { pobožnost } \\
\text { (Osjećam iskustvo osobne } \\
\text { povezanosti s Bogom) }\end{array}$ & $\begin{array}{c}\text { od } 1 \text { (ne } \\
\text { slažem se) do } \\
5 \text { (slažem se) } \\
\end{array}$ \\
\hline & & & $\begin{array}{c}\text { Dimenzija: Povezanost s } \\
\text { drugim ljudima }\end{array}$ & \\
\hline & & & \begin{tabular}{|c|}
$\mathrm{X}_{3}-$ religioznost unutar \\
religijske zajednice \\
(Koliko često sudjelujete u \\
religijskim službama u crkvi ili \\
džamiji ili na drugom mjestu?)
\end{tabular} & $\begin{array}{c}\text { od nikada do } \\
\text { ne znam }\end{array}$ \\
\hline & & & \begin{tabular}{|c|}
$\mathrm{X}_{4}-$ religioznost izvan vlastite \\
religijske zajednice \\
(Provodite li slobodno vrijeme \\
s ljudima koji pripadaju drugoj \\
religiji?)
\end{tabular} & $\begin{array}{c}\text { od nikada do } \\
\text { ne znam }\end{array}$ \\
\hline \multirow{6}{*}{$\begin{array}{l}2 . \\
M \\
O \\
D \\
\text { E } \\
\text { L }\end{array}$} & \multirow{6}{*}{$\begin{array}{l}\text { Vjerska sloboda - } \\
\text { forum externum } \\
\text { (Prosjek varijabli: } \\
\text { Vlada bi trebala } \\
\text { omogućiti da } \\
\text { se religija može } \\
\text { podučavati u } \\
\text { školama; } \\
\text { Država bi trebala } \\
\text { poštovati pravo } \\
\text { vjerskih zajednica da } \\
\text { osnivaju škole; } \\
\text { U školama bi } \\
\text { učenicima trebalo } \\
\text { biti omogućeno } \\
\text { vrijeme i prostor za } \\
\text { molitvu; } \\
\text { Država ne bi } \\
\text { trebala zabranjivati } \\
\text { nastavnicima da iz } \\
\text { religijskih razloga } \\
\text { nose marame na } \\
\text { glavi.) }\end{array}$} & \multirow{6}{*}{$\begin{array}{l}\text { od } 1 \text { (ne } \\
\text { slažem } \\
\text { se) do } 5 \\
\text { (slažem se) }\end{array}$} & \begin{tabular}{|c|} 
RELIGIOZNOST \\
Dimenzija: Osobna religioznost \\
\end{tabular} & \\
\hline & & & $\begin{array}{c}\mathrm{X}_{1}-\text { doktrinarna } \\
\text { pravovjernost } \\
\text { (Vjerujem da je Bog temelj } \\
\text { svega što postoji.) }\end{array}$ & $\begin{array}{c}\text { od } 1 \text { (ne } \\
\text { slažem se) do } \\
5 \text { (slažem se) }\end{array}$ \\
\hline & & & $\begin{array}{c}\mathrm{X}_{2}-\text { pobožnost } \\
\text { (Osjećam iskustvo osobne } \\
\text { povezanosti s Bogom.) }\end{array}$ & $\begin{array}{c}\text { od } 1 \text { (ne } \\
\text { slažem se) do } \\
5 \text { (slažem se) } \\
\end{array}$ \\
\hline & & & $\begin{array}{c}\text { Dimenzija: Povezanost s } \\
\text { drugim ljudima }\end{array}$ & \\
\hline & & & \begin{tabular}{|c|}
$\mathrm{X}_{3}-$ religioznost unutar \\
religijske zajednice \\
(Koliko često sudjelujete $\mathrm{u}$ \\
religijskim službama u crkvi ili \\
džamiji ili na drugom mjestu?) \\
\end{tabular} & $\begin{array}{l}\text { od nikada do } \\
\text { ne znam }\end{array}$ \\
\hline & & & $\begin{array}{c}\mathrm{X}_{4}-\text { religioznost izvan vlastite } \\
\text { religijske zajednice } \\
\text { (Provodite li slobodno vrijeme } \\
\text { s ljudima koji pripadaju drugoj } \\
\text { religiji?) }\end{array}$ & $\begin{array}{c}\text { od nikada do } \\
\text { ne znam }\end{array}$ \\
\hline
\end{tabular}


Temeljem konceptualnog modela formulirane su sljedeće hipoteze:

H1 - Pretpostavlja se pozitivna povezanost između religioznosti unutar vlastite zajednice (češće sudjelovanje na vjerskim obredima) i vjerske slobode (forum externum).

H2 - Pretpostavlja se pozitivna povezanost između religioznosti u dimenziji povezanosti s drugim ljudima i vjerske slobode u dimenziji forum internum.

Statistička metoda i kriteriji empirijskog istraživanja ovog rada obuhvaćaju: Kreaciju kriterijske varijable - vjerska sloboda forum externum kao aritmetičke sredine nekoliko stavaka. ${ }^{34}$ Prije višestruke regresije izračunate su aritmetičke sredine kriterijske varijable i prediktora. Statistička značajnost regresijskih koeficijenata u modelima je testirana ANOVA metodom. Izabrane su samo korelacije $\mathrm{s}$ koeficijentom korelacije $\geq 0,15$. Korištena je ENTER metoda višestruke regresije. Faktor inflacije varijance (VIF) je uvijek bio manji od 10 (VIF <10), što pokazuje da nije bilo multikolinearnosti među prediktorima. Analizom su uzete kao relevantne one prediktorske varijable čija je p vrijednost manja od 0,05.

\section{Povezanost religioznosti te stavove i iskustva o vjerskoj slobodi kod religiozno deklariranih mladih u Hrvatskoj - empirijska analiza}

Operacionalizacija stavova i iskustva vezanih uz vjersku slobodu kod religiozno deklariranih mladih u Hrvatskoj provedena je na temelju višestruke regresijske analize za koju su sistematizirana dva modela višestruke analize (usp. tablicu 1). U ovom će poglavlju rezultati za svaki model biti prikazani u posebnom podnaslovu.

\subsection{Vjerska sloboda (forum internum) i religioznost}

U prvom modelu višestruke regresije istraživana je povezanost vjerske slobode (forum internum) kao kriterijske varijable i četiri prediktora religioznosti na 911 religioznih ispitanika. ${ }^{35}$ Aritmetičke sredine kriterija i prediktora prikazane su u sljedećoj tablici.

\footnotetext{
${ }^{34}$ Stavke su: Vlada bi trebala omogućiti da se religija može podučavati u školama. Država bi trebala poštovati pravo vjerskih zajednica da osnivaju škole. U školama bi učenicima trebalo biti omogućeno vrijeme i prostor za molitvu. Država ne bi trebala zabranjivati nastavnicima da iz religijskih razloga nose marame na glavi.

${ }^{35}$ Iz ove je analize isključeno 125 nereligioznih osoba, a 43 osobe kojima nije bilo moguće izračunati prosjek jer je nedostajala neka od četiri varijable, te 207 osoba kojima je nedostajala neka od nezavisnih varijabli. Preostao je N=911.
} 
Tablica 2. Aritmetičke sredine kriterija i prediktora u prvom modelu regresijske analize.

\begin{tabular}{|c|c|c|}
\hline $\begin{array}{l}\text { Kriterijska } \\
\text { varijabla Y }\end{array}$ & $\begin{array}{l}\text { Vjerska sloboda (forum internum) } \\
\text { (Koliko ste često osobno bili nepravedno tretirani zbog religijske pripadnosti?) }\end{array}$ & 1,65 \\
\hline Prediktor $\mathrm{X}_{1}$ & $\begin{array}{l}\text { Osobna religioznost - doktrinarna pravovjernost } \\
\text { (Vjerujem da je Bog temelj svega što postoji.) }\end{array}$ & 3,86 \\
\hline Prediktor $\mathrm{X}_{2}$ & $\begin{array}{l}\text { Osobna religioznost - pobožnost } \\
\text { (Osjećam iskustvo osobne povezanosti s Bogom.) }\end{array}$ & 3,47 \\
\hline Prediktor $\mathrm{X}_{3}$ & $\begin{array}{l}\text { Povezanost s drugim ljudima - religioznost unutar vlastite religijske } \\
\text { zajednice } \\
\text { (Koliko često sudjelujete u religijskim službama u crkvi ili džamiji ili na drugom } \\
\text { mjestu?) }\end{array}$ & 3,49 \\
\hline Prediktor $\mathrm{X}_{4}$ & $\begin{array}{l}\text { Povezanost s drugim ljudima - religioznost izvan vlastite religijske } \\
\text { zajednice } \\
\text { (Provodite li slobodno vrijeme s ljudima koji pripadaju drugoj religiji?) }\end{array}$ & 2,82 \\
\hline
\end{tabular}

Izvor: »Religija i ljudska prava« (2014.).

Vrijednosti regresijskih koeficijenata s pripadajućom standardnom greškom, t vrijednosti i p vrijednosti prikazani su u sljedećoj tablici.

Tablica 3. Kriterij: Nepravedan tretman zbog religijske pripadnosti.

\begin{tabular}{|l|c|c|c|c|c|}
\hline & \multicolumn{2}{|c|}{$\begin{array}{c}\text { Nestandardizirani } \\
\text { koeficijenti }\end{array}$} & $\begin{array}{c}\text { Standardizirani } \\
\text { koeficijenti }\end{array}$ & \multirow{2}{*}{ t } & p \\
\cline { 2 - 5 } & B & $\begin{array}{c}\text { Standardna } \\
\text { pogreška }\end{array}$ & Beta & & \\
\hline (Konstanta) & 1,186 & 0,151 & & 7,867 & $<0,001$ \\
\hline $\begin{array}{l}\text { Vjerujem da je Bog temelj svega } \\
\text { što postoji. }\end{array}$ & $-0,101$ & 0,041 & $-0,121$ & $-2,483$ & 0,013 \\
\hline $\begin{array}{l}\text { Osjećam iskustvo osobne } \\
\text { povezanosti s Bogom. }\end{array}$ & 0,079 & 0,042 & 0,089 & 1,897 & 0,058 \\
\hline $\begin{array}{l}\text { Koliko često sudjelujete u } \\
\text { religijskim obredima u crkvi ili } \\
\text { džamiji ili na drugom mjestu? }\end{array}$ & 0,086 & 0,028 & 0,113 & 3,080 & 0,002 \\
\hline $\begin{array}{l}\text { Provodite li slobodno vrijeme } \\
\text { s ljudima koji pripadaju drugoj } \\
\text { religiji? }\end{array}$ & 0,102 & 0,028 & 0,118 & 3,616 & $<0,001$ \\
\hline
\end{tabular}

Izvor: »Religija i ljudska prava« (2014.)

$\mathrm{Na}$ osnovu dobivenih rezultata analize može se zaključiti da su u navedenom modelu statistički značajne sve navedene varijable $(\mathrm{p}<0,05)$, osim prediktora $\mathrm{X}_{2}$ (Osjećam iskustvo osobne povezanost s Bogom) budući da je njezina $\mathrm{p}$ vrijednost veća od $0,05(\mathrm{p}=0,058)$. Stoga je taj prediktor isključena iz daljnjih rezultata. U ANOVA analizi dobiveni rezultati $(\mathrm{F}=7,173 \mathrm{p}<0,001)$ pokazuju značajnost ovog modela. Koeficijent korelacije (R) je 0,174 što znači da između vjerskih sloboda (forum internum) kao kriterijske varijeble i triju prediktora $\mathrm{X}_{1}$, $\mathrm{X}_{3} \mathrm{i} \mathrm{X}_{4}$ postoji slaba pozitivna korelacija. Koeficijent determinacije $\left(\mathrm{R}^{2}\right)$ je 0,030 
što znači da je vezom između promatrane kriterijske varijable vjerske slobode (forum internum) i prediktora $\mathrm{X}_{1}, \mathrm{X}_{3} \mathrm{i} \mathrm{X}_{4}$ objašnjeno 3,0 \% odstupanja (varijacija). Korigirani koeficijent determinacije (Adjusted $R$ Square) je 0,026.

Jednadžba višestruke regresije glasi:

$$
\hat{Y}=1,186-0,101 X_{1}+0,086 X_{3}+0,102 X_{4}
$$

Kada je riječ o dimenziji osobne religioznosti, analiza pokazuje da mladi vjernici koji više vjeruju da je Bog temelj svega što postoji $\left(\mathrm{X}_{1}\right)$ imaju osjećaj da su rjeđe nepravedno tretirani zbog religijske pripadnosti (forum internum). Religioznost u dimenziji povezanosti s drugim ljudima pokazuje da oni mladi vjernici koji češće sudjeluju u vjerskim obredima imaju osjećaj da su češće nepravedno tretirani zbog religijske pripadnosti (forum internum). Oni mladi vjernici koji češće provode slobodno vrijeme s pripadnicima drugih religija također su bili češće nepravedno tretirani zbog religijske pripadnosti (forum internum).

\subsection{Vjerska sloboda (forum externum) i religioznost}

U drugom modelu višestruke regresije analizirana je povezanost vjerske slobode (forum externum) kao kriterijske varijable i četiri prediktora religioznosti na 911 religioznih ispitanika. ${ }^{36}$ Aritmetičke sredine kriterija i prediktora prikazane su u sljedećoj tablici.

Tablica 4. Aritmetičke sredine kriterija i prediktora u drugom modelu regresijske analize.

\begin{tabular}{|l|l|c|}
\hline $\begin{array}{l}\text { Kriterijska } \\
\text { varijabla Y }\end{array}$ & $\begin{array}{l}\text { Vjerska sloboda (forum externum) } \\
\text { (Prosjek varijabli: Vlada bi trebala omogućiti da se religija može podučavati u } \\
\text { školama; Država bi trebala poštovati pravo vjerskih zajednica da osnivaju škole; } \\
\text { Uškolama bi učenicima trebalo biti omogućeno vrijeme i prostor za molitvu; } \\
\text { Država ne bi trebala zabranjivati nastavnicima da iz religijskih razloga nose } \\
\text { marame na glavi.) }\end{array}$ & 3,74 \\
\hline Prediktor $\mathbf{X}_{1}$ & $\begin{array}{l}\text { Osobna religioznost - doktrinarna pravovjernost } \\
\text { (Vjerujem da je Bog temelj svega što postoji.) }\end{array}$ & 3,87 \\
\hline Prediktor $\mathbf{X}_{2}$ & $\begin{array}{l}\text { Osobna religioznost - pobožnost } \\
\text { (Osjećam iskustvo osobne povezanosti s Bogom.) }\end{array}$ & 3,47 \\
\hline Prediktor $\mathbf{X}_{3}$ & $\begin{array}{l}\text { Povezanost s drugim ljudima - religioznost unutar vlastite religijske } \\
\text { zajednice } \\
\text { (Koliko često sudjelujete u religijskim službama u crkvi ili džamiji ili na drugom } \\
\text { mjestu?) }\end{array}$ & 3,49 \\
\hline Prediktor $\mathbf{X}_{4}$ & $\begin{array}{l}\text { Povezanost s drugim ljudima - religioznost izvan vlastite religijske } \\
\text { zajednice } \\
\text { (Provodite li slobodno vrijeme s ljudima koji pripadaju drugoj religiji?) }\end{array}$ & 2,82 \\
\hline
\end{tabular}

Izvor: »Religija i ljudska prava« (2014.).

\footnotetext{
${ }^{36}$ Iz ove je analize isključeno 125 nereligioznih osoba, a 43 osobe kojima nije bilo moguće izračunati prosjek jer je nedostajala neka od četiri varijable, te 207 osoba kojima je nedostajala neka od nezavisnih varijabli. Preostao je N=911.
} 
Vrijednosti regresijskih koeficijenata sa pripadajućom standardnom pogreškom, $\mathrm{t}$ vrijednosti i p vrijednosti prikazane su u sljedećoj tablici:

Tablica 5. Kriterij: Vjerska sloboda - forum externum.

(Prosjek varijabli: Vlada bi trebala omogućiti da se religija može podučavati u školama; Država bi trebala poštovati pravo vjerskih zajednica da osnivaju škole; U školama bi učenicima trebalo biti omogućeno vrijeme i prostor za molitvu; Država ne bi trebala zabranjivati nastavnicima da iz religijskih razloga nose marame na glavi.)

Koeficijanti ${ }^{\mathrm{a}}$

\begin{tabular}{|l|c|c|c|c|c|}
\hline & \multicolumn{2}{|c|}{$\begin{array}{c}\text { Nestandardizirani } \\
\text { koeficijenti }\end{array}$} & $\begin{array}{c}\text { Standardizirani } \\
\text { koeficijenti }\end{array}$ & \multirow{2}{*}{ t } & Sig. \\
\cline { 2 - 5 } & B & $\begin{array}{c}\text { Standardna } \\
\text { pogreška }\end{array}$ & Beta & & \\
\hline (Konstanta) & 2,683 & 0,102 & & 26,260 & $<0,001$ \\
\hline $\begin{array}{l}\text { Vjerujem da je Bog temelj svega } \\
\text { što postoji. }\end{array}$ & 0,162 & 0,028 & 0,268 & 5,879 & $<0,001$ \\
\hline $\begin{array}{l}\text { Osjećam iskustvo osobne } \\
\text { povezanosti s Bogom. }\end{array}$ & 0,072 & 0,028 & 0,112 & 2,537 & 0,011 \\
\hline $\begin{array}{l}\text { Koliko često sudjelujete u } \\
\text { religijskim obredima u crkvi ili } \\
\text { džamiji ili na drugom mjestu? }\end{array}$ & 0,050 & 0,019 & 0,091 & 2,631 & 0,009 \\
\hline $\begin{array}{l}\text { Provodite li slobodno vrijeme } \\
\text { s ljudima koji pripadaju drugoj } \\
\text { religiji? }\end{array}$ & 0,004 & 0,019 & 0,006 & 0,185 & 0,853 \\
\hline
\end{tabular}

Izvor: »Religija i ljudska prava« (2014.).

Na osnovu dobivenih rezultata analize može se zaključiti da su u navedenom modelu statistički značajni svi prediktori $(\mathrm{p}<0,05)$, osim prediktora $\mathrm{X}_{4}(\mathrm{~F} 42)$ budući da je p vrijednost veća od 0,05 ( $\mathrm{p}=0,853)$. Stoga je on isključen iz daljnjih rezultata. U ANOVA analizi dobiveni rezultati $(\mathrm{F}=44,839 \mathrm{p}<0,001)$ pokazuju značajnost ovog modela. Koeficijent korelacije (R) je 0,407, što znači da između vjerskih sloboda (forum externum) kao kriterijske varijable i triju prediktora $\mathrm{X}_{1}, \mathrm{X}_{2} \mathrm{i} \mathrm{X}_{3}$ postoji osrednja pozitivna korelacija. Koeficijent determinacije $\left(\mathrm{R}^{2}\right)$ je 0,165 , što znači da je vezom između promatrane kriterijske varijable $Y$ i prediktora $\mathrm{X}_{1}, \mathrm{X}_{2}$ i $\mathrm{X}_{3}$ objašnjeno 16,5 \% odstupanja (varijacija). Korigirani koeficijent determinacije (Adjusted $R$ Square) je 0,162.

Jednadžba multiple regresije glasi:

$$
\hat{Y}=2,683+0,162 X_{1}+0,072 X_{2}+0,050 X_{3}
$$

Višestruka regresija u drugom modelu pokazuje da se religiozno deklarirani mladi koji više vjeruju da je Bog temelj svega što postoji $\left(\mathrm{X}_{1}\right)$ i više slažu $\mathrm{s}$ vjerskom slobodom u forum externum dimenziji. Oni mladi vjernici koji imaju jači osjećaj iskustva osobne povezanosti s Bogom $\left(\mathrm{X}_{2}\right)$ se više slažu s vjerskom slobodom u forum externum dimenziji. 
Analiza religioznosti u dimenziji povezanosti s drugim ljudima pokazuje da oni mladi vjernici koji češće sudjeluju u vjerskim obredima se više slažu s vjerskom slobodom u njezinoj dimenziji forum externum.

$\mathrm{U}$ interpretaciji rezultata višestruke regresijske analize posebno se ističe, između ostalog, zaključak da prediktor religioznosti doktrinarna pravovjernost utječe istovremeno na obje dimenzije vjerske slobode. Naime, oni mladi vjernici koji više vjeruju u Boga kao temelj svega što postoji su rjeđe nepravedno tretirani zbog religijske pripadnosti (forum internum) i više se slažu s vjerskom slobodnom (forum externum). Istovremeno, analiza pokazuje da osobna religioznost pozitivno utječe na stav o vjerskoj slobodi (forum externum). Religioznost unutar vlastite zajednice ima utjecaj na vjersku slobodu (forum externum), naime oni koji češće sudjeluju na vjerskim obredima se više slažu s vjerskom slobodom (forum externum).

Religioznost u dimenziji povezanosti s drugim ljudima izvan vlastite religijske zajednice pokazuje da oni mladi vjernici koji češće sudjeluju u vjerskim obredima imaju osjećaj da su češće nepravedno tretirani zbog religijske pripadnosti (forum internum) te da oni koji češće provode vrijeme s pripadnicima drugih religija su i češće nepravedno tretirani zbog religijske pripadnosti.

Kada je riječ o formuliranim hipotezama, prva hipoteza $(\mathrm{H} 1)$ je potvrđena, s obzirom da su rezultati pokazali pozitivnu povezanost između religioznosti unutar vlastite zajednice (češće sudjelovanje na vjerskim obredima) i vjerske slobode (forum externum). Druga hipoteza (H2) je opovrgnuta jer su rezultati pokazali da ne postoji pozitivna povezanost između prediktora religioznosti $u$ dimenziji povezanosti s drugim ljudima i vjerske slobode (forum internum).

\section{Zaključak}

U ovom je radu proučavana povezanost religioznosti te stavova i iskustava o vjerskoj slobodi kod religiozno deklariranih mladih u Hrvatskoj. U teorijskim osnovama rada prikazana je vjerska sloboda kao višedimenzionalno ljudsko pravo te odnos Katoličke crkve i vjerske slobode kroz povijest. Empirijski dio rada temeljio se na hrvatskom istraživanju »Religija i ljudska prava « (2014.) koje je provedeno u sklopu međunarodnog empirijskog istraživačkog programa »Religion and Human Rights« (2012.-2019.). Istraživačko pitanje empirijskog dijela rada, u okviru kojeg je provedena višestruka regresijska analiza, glasilo je: Postoji li, na temelju istraživanja »Religija i ljudska prava« (2014.), povezanost između religioznosti te stavova i iskustava o vjerskoj slobodi (forum internum i forum externum) kod religiozno deklariranih mladih u Hrvatskoj, i - ako da - koja su njezina obilježja? Uvid u same stavove religiozno deklariranih mladih je pružila povezanost između prediktora religioznosti i vjerske slobode u forum internum dimenziji, a uvid u njihova iskustva 
je pružila povezanost između prediktora religioznosti i vjerske slobode $\mathrm{u}$ forum externum dimenziji.

Rezultati višestruke regresijske analize su pokazali, s jedne strane, da tri prediktora religioznosti (doktrinarna pravovjernost, pobožnost i religioznost unutar vlastite religijske zajednice) imaju pozitivan utjecaj na stavove mladih, tj. slaganje $\mathrm{s}$ vjerskom slobodom $\mathrm{u}$ forum externum dimenziji. $\mathrm{S}$ druge strane, uvid $\mathrm{u}$ iskustva mladih vjernika pružila je povezanost vjerske slobode $\mathrm{u}$ forum internum dimenziji (nepraved no tretiranje zbog religijske pripadnosti) i religioznosti, a upravo ta povezanost je bila negativna jer oni religiozno deklarirani mladi koji češće sudjeluju na vjerskim obredima i češće provode vrijeme s pripadnicima drugih religija su i češće nepravedno tretirani zbog religijske pripadnosti. Jedino na razini osobne religioznosti (doktrinarne pravovjernosti), oni religiozno deklarirani mladi koji više vjeruju u Boga su rjeđe nepravedno tretirani zbog religijske pripadnosti (forum internum).

Zaključno se na temelju dobivenih rezultata može konstatirati da religioznost daje bitan doprinos u ostvarenju kolektivne forum externum dimenzije vjerske slobode, ali ujedno i daje uvid u deficite kada je riječ o ostvarenju vjerske slobode na individualnoj forum internum dimenziji. 


\section{Marijana Kompes*}

Connection of religiosity, attitutes and experiences of religious freedom among young people in Croatia declared as religious

\section{Summary}

Religious freedom is one of the oldest, fundamental and inviolable human rights. At the same time, religious freedom, as a human right, is a multidimensional right that protects the individual and the collective dimension of freedom (forum internum and forum externum). Starting from the perspective of the social teaching of the church, the theoretical part of the paper shows religious freedom as a multidimensional human right and provides insight into the relationship between the Catholic Church and religious freedom through history. The empirical part of this paper is based on the Croatian research $»$ Religija i ljudska prava« (»Religion and Human Rights«) (2014), which was conducted within the scope of the international empirical research program »Religion and Human Rights« (2012-2019).

Based on the mentioned research, this paper explores the connection of religiosity, attitudes and experiences of religious freedom (forum internum and forum externum) among young people in Croatia declared as religious at the age of 17 to 19, most of whom are Catholics. The results of the empirical analysis (multiple regression analysis) show that the predictors of religiosity have an impact on the attitudes and experiences of young people in Croatia declared as religious as regards religious freedom, in both of its dimensions.

Key words: religious freedom, religiosity, young people in Croatia declared as religious, Catholic Church.

(na engl. prev. Elena Lalić)

\footnotetext{
* Marijana Kompes, PhD, Mag. phil., Post doctorand, Catholic University of Croatia, Zagreb; Address: Ilica 242, HR-10000 Zagreb, Croatia; E-mail: marijana.kompes@unicath.hr.
} 